\title{
Potency and Spatial Distribution of Trochus sp. In Intertidal Zone of Rhun Island Waters, Banda Sub-District, Central Maluku Regency
}

\author{
Safrudin La Abukena \\ Doctoral Program, Bogor Agricultural Institute, Bogor- Indonesia \\ Yusli Wardiatno \\ Bogor AgriculturalInstitute, Bogor- Indonesia \\ Isdradjat Setyobudiandi \\ Bogor AgriculturalInstitute, Bogor- Indonesia \\ Abraham S Khouw \\ Faculty of Fisheries, Unpatti, Ambon- Indonesia
}

Received: January 19, 2014

Accepted: January 28, 2014

doi:10.5296/emsd.v3i1.5421

URL: http://dx.doi.org/10.5296/emsd.v3i1.5421

\begin{abstract}
Trochussp belongs to class gastropods in order Archaeo gastropoda. Most of this mollusks live in intertidal zone of coastal waters area. Utilization on fishery resource by inappropriate-based information toward this potential resource will cause population structure changes inflicting extinction. This study aims to know the size, density, potency, diversity index, homogeneity index, dominance index and distribution pattern of Trochus sp. Research site is located in intertidal zones which are divided into three zones (high, middle and low) in an area width of $111.000 \mathrm{~m}^{2}$, while the observed area is $20.875 \mathrm{~m}^{2}(18.81 \%)$. Applied method is transect quadrant in size of $5 \times 5 \mathrm{~m}$ with $25 \mathrm{~m}$ of transect distance which is perpendicular to the shoreline and this quadrant is set based on the line transect with no distance. The findings show that dominant species in high and mid intertidal zones is T. Pyramis, while the dominant species in low zone is T.niloticus. Average size of Trochus sp. basal diameter increases in a deeper waters; this is in contrast to the density. Trochus sp. potency in high zone is 46 ind.ha $^{-1}, 28$ ind ha $^{-1}$ in the mid zone and 25 ind.ha $^{-1}$ in the low zone. Diversity index value of Trochus sp.is moderate, low. Obtained distribution pattern of Trochus sp. in research sites from the three zones are clumped pattern based on habitat and food.
\end{abstract}

Keywords: Trochus Sp, Potency, Spatial Distribution, PulauRhun 


\section{Macrothink}

\section{Introduction}

Trochus sp.belongs to class gastropods in order Archaeo gastropoda in habiting intertidal zone of coastal waters (Arifin and Pradina, 1993, Nurdinet al., 2010), coral reef and intertidal flat in depth of up to $>10 \mathrm{~m}$ (Woodhams. 2009). It also lives in waters with a wide coral reef flat (Lalli and Parsons. 2001). Ease of extraction conducted by people allows excessive utilization toward this marine resource either for food, side dish alternatives, raw material of jewelry, souvenirs or paint compound and high protein content in its meat as well (Dolorosa, et al., 2010).

Commonly utilized Trochus in coastal community of Maluku are Trochusniloticus, T.piramys, T.Maculatus, and T.radiatus (Purnomowati R. 2001). Continuous human activities disregarding bio-ecological aspect will decrease resource potency of Trochussp and habitat degradation. Therefore, it needs an effort to protect this marine resource sustainability.

Recently faced problem is lack of information on Trochus sp. potency, especially in Rhun Island, and knowledge related to this biota. This condition encourages local people to exploit more disregarding its potency and ecological condition. In order to solve the problem, there should be a study on Trochus sp.potency and spatial distribution.

This study aims to understand natural population condition of Trochus sp.covering: size, density, diversity index, homogeneity index, dominance index and distribution pattern. Expected benefit of the study is to be the basic information for resource management of Trochus sp. in Lokong coastal waters, PulauRhun village, Banda Sub-district, Central Maluku Regency.

\section{Research Method}

\subsection{Research Time and Site}

This study is conducted from May to July, 2013 in coastal waters of Rhun Island village, Banda Sub-district, Central Maluku Regency. Location of the study lies at southern latitude of $04^{\circ} 31^{\prime \prime} 17.2^{\prime}$ and longitude east of $129^{\circ} 40^{\prime} 24.6$ (Figure 1).

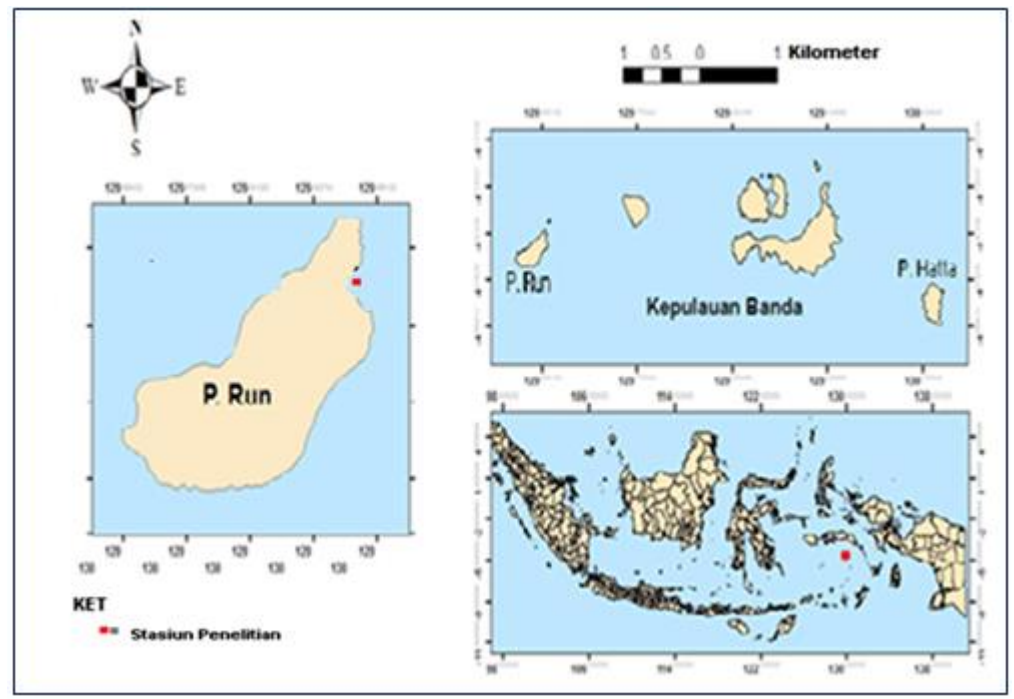

Figure 1. Map of Research Site 


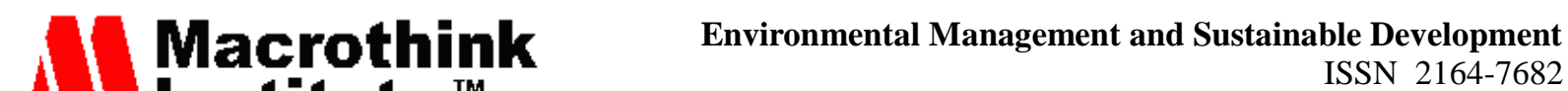 2014, Vol. 3, No. 1}

\subsection{Sampling and Data Collection Method}

Sampling is aimed to the three kinds of intertidal zones, i.e., high, middle and low. High zone is characterized by small coral pieces, seaweed and sand-dominated substrate, middle zone is characterized by reef block substrate and small number of living coral, while low zone is characterized by living coral, macroalgae and microalgae.

Applied method is transect quadrant, while transect distance is $25 \mathrm{~m}$ in quadrant size of $5 \times 5$ $\mathrm{m}$ which is set by following transect with no distance.

\subsection{Data Analysis}

a) Density

Species density refers to the number of individuals of species in a certain volume or area and it is calculated based on formula as proposed by Dahuri et al., (1993) as follows:

$$
K=\frac{\sum x_{i}}{n}
$$

Description:

$\mathrm{K}=$ Sea cucumber density

$\mathrm{x}_{\mathrm{i}}=$ Number of sea cucumber in $i$ thsample unit

$\mathrm{n}=$ Number of $i$ th sample unit

b) Potency

Potency is calculated by applying equation below:

$$
P=\bar{X} \cdot A
$$

Description

$$
\begin{aligned}
& \mathrm{P}=\text { Potency } \\
& \mathrm{X}=\text { Density }\left(\mathrm{ind} / \mathrm{m}^{2}\right) \\
& \mathrm{A}=\text { Width of research area }
\end{aligned}
$$

c) Diversity and Homogeneity Index

Diversity index is an overview that reflects community structure of organism which can make information analysis process on organism species and its number easier. The more biota species inhabiting waters, the higher of its diversity.Shannon - Wiener index calculator (Magguran, 1955 in Hartati and Awaluddin (2007) is presented as follows:

$$
H^{\prime}=-\sum_{i=1}^{s} P i \operatorname{Ln} P i
$$

Description:

$$
\begin{aligned}
& \mathrm{H}^{\prime}=\text { Diversity index } \\
& \mathrm{Pi}=\mathrm{ni} / \mathrm{N} \\
& \mathrm{N}=\text { Number of } i \text { th individual species } \\
& \mathrm{S}=\text { Number of } i \text { th biota species }
\end{aligned}
$$

Based on equation above, Shannon-Wiener diversity is categorized as follows: 


\section{MlMacrothink}

$$
\begin{array}{ll}
\mathrm{H}<1.0 & =\text { Low } \\
1.0<\mathrm{H}<3.0 & =\text { Average } \\
\mathrm{H}>3.0 & =\text { High }
\end{array}
$$

Diversity index can be calculated by equation as follows:

$$
e=\frac{H^{\prime}}{H_{\text {maks }}}
$$

Description:

$$
\begin{aligned}
& H^{\prime}=\text { Diversity Index } \\
& H_{\text {maks }}=\ln S
\end{aligned}
$$

Homogeneity index value is around $0-1$. If the homogeneity index is close to 0 , there is an inclination of species dominance caused by environmental factors instability in the ecosystem. If the homogeneity index is close to 1 , it shows that the ecosystem is relatively stable, i.e., when the number of every species is relatively equal (Brower danZar 1977).

d) Dominance Index

Applied dominance index is Simpson's dominance index (Simpson, 1949 in Krebs. 1989), as follows:

$$
D=\sum_{i=1}^{s}\left[\frac{n_{i}-\left(n_{i}-1\right)}{N(N-1)}\right]
$$

Description:

$\mathrm{D}=$ Simpson's dominance index

$\mathrm{ni}=$ Number of individuals of the $i$ th species

$\mathrm{N}=$ Total number of individuals

$\mathrm{s}=$ Total of sample

The value of $\mathrm{D}$ is categorized as follows:

$0<\mathrm{D} \leq 0.5=$ Less dominant

$0.5<\mathrm{D} \leq 0.75=$ Moderate dominant

$0.75<\mathrm{D} \leq 1.00=$ High dominant

e) Distribution Pattern

Knowledge on distribution pattern is important to understand the clump level of individuals which can impact population. Distribution pattern of Trochus sp.is analyzed based on distribution pattern as developed by Morisita (1962) in Khouw (2009) by the following equation:

$$
I_{d}=n \frac{\sum x^{2}-\sum x}{\left(\sum x\right)^{2}-\sum x}=n \frac{\sum[x(x-1)]}{\left.\sum x\left(\sum x-1\right)\right)}
$$

Description:

$\mathrm{I}_{\mathrm{d}}=$ Morisita's distribution index

$\mathrm{n}=$ Number of samples

$\sum \mathrm{x}=$ Total of individuals in every quadrant 
$\sum \mathrm{x}^{2}=$ Squared total of individuals in every quadrant

Below is criterion of each value:

$\mathrm{Id}=1$ indicates a random distribution

Id $>1$ indicates a clumped distribution

Id $<1$ indicates a uniform distribution

\section{Findings and Discussion}

\subsection{Description on Research Site}

Coastal waters of Rhun Island in intertidal zone has a slope coastal topography with substrate type of sand, seaweed, small coral pieces, reef block and living coral.

Habitat structure of high zone are sand, seaweed and small coral pieces as well as some types of macroalgae and microalgae under water depth of 0.1 to $2 \mathrm{~m}$. Research site area is 41,000 $\mathrm{m}^{2}$ in observed area of $8,125 \mathrm{~m}^{2}$ or $18.82 \%$ of research site area and the total of observed quadrant (325 quadrants). Types of Trochus sp.found in this zone are T. piramys, T. niloticus, T. makulatus and T. radiatus attached to leaves of seaweed as their foraging habitat because the leaves has a great number of epiphytes as the food of various kinds of gastropods. The dominant types of gastropods isT. pyramis, then followed by T. niloticus, T. maculatusand $T$. radiatus.

Mid zone has habitat structure of coral fracture, dead reef block, small number of living coral, and some macroalgae and microalgae in depth of 2.0 to $3 \mathrm{~m}$. Research area is $48,000 \mathrm{~m}^{2}$ in observed area of $8,875 \mathrm{~m}^{2}$ or $18.48 \%$ of the whole research site area. The number of observed quadrant is 355 quadrants. Types of Trochus sp.found in this zone are T. piramys, T. niloticus, T. makulatus and $T$. radiatus. The dominant species is $T$. pyramis, then followed by $T$. niloticus, T. maculatus and T. radiatus.

Habitat structure of low zone are dead reef block, soft coral with living coral dominating this zone. It also has much macro algae and microalgae in depth of 3.0 to $4 \mathrm{~m}$. Research site area is $22,000 \mathrm{~m}^{2}$ or $17.61 \%$ of research site area with 155 observed quadrants. Types of Trochus sp. found in this zone are T. niloticus, $T$. piramys, while T. makulatus and T. radiates cannot be found in this area. Types of dominant Trochussp isspesies T. niloticus and T. pyramis.

\subsection{Size of Trochus sp.}

Result of analysis on the size of Trochus sp. in intertidal zone is presented in Table 1.

Table 1. Size of Trochus sp. in Intertidal Zone

\begin{tabular}{|l|l|l|r|r|r|}
\hline $\begin{array}{l}\text { Intertidal } \\
\text { zone }\end{array}$ & $\begin{array}{l}\text { Depth } \\
(\mathrm{m})\end{array}$ & Species & \multicolumn{1}{l|}{$\begin{array}{l}\text { Diameter } \\
(\mathrm{mm})\end{array}$} & $\begin{array}{l}\text { Height of } \\
\text { Apex }(\mathrm{mm})\end{array}$ & \multicolumn{1}{l|}{$\begin{array}{l}\text { Diameter of } \\
\text { basal }(\mathrm{mm})\end{array}$} \\
\hline \multirow{3}{*}{ High } & & T. niloticus & 21.62 & $8.51-16.87$ & $12.21-32.15$ \\
\cline { 3 - 6 } & \multirow{3}{*}{$0.1-2 \mathrm{~m}$} & $T$. pyramis & 15.93 & $8.15-23.54$ & $8.10-23.40$ \\
\cline { 3 - 6 } & & T. maculatus & 13.09 & $7.12-14.56$ & $10.83-16.03$ \\
\cline { 3 - 6 } & & T. radiatus & 12.72 & $10.21-15.12$ & $10.35-15.71$ \\
\hline
\end{tabular}




\begin{tabular}{|c|c|c|c|c|c|}
\hline \multirow{4}{*}{ Middle } & \multirow{4}{*}{$2.0-3 \mathrm{~m}$} & T. niloticus & 36.18 & $36.39-51.29$ & $31.31-42.33$ \\
\hline & & T. pyramis & 29.49 & $17.91-33.60$ & 25.91-34.46 \\
\hline & & T. maculatus & 28.88 & $16.01-37.67$ & $20.66-36.58$ \\
\hline & & T.radiatus & 24.90 & $17.54-27.54$ & $20.78-29.05$ \\
\hline \multirow{4}{*}{ Low } & \multirow{4}{*}{$3.0-4 \mathrm{~m}$} & T. niloticus & 49.55 & 49.31-61.51 & $40.08-62.26$ \\
\hline & & T. pyramis & 38.06 & $26.12-35.42$ & $33.42-42.05$ \\
\hline & & T. maculatus & - & - & - \\
\hline & & T.radiatus & - & - & - \\
\hline
\end{tabular}

Table 1 shows that there are 4 types of Trochus sp. in intertidal zone, they are $T$. niloticus, $T$. pyramis, T. maculatus and T. radiatus which has various average size of basal diameter in high and mid zone, but T. maculatus and T. radiates could not be found in low zone. Due to its tiny size, both of Trochus sp. could not be found in low zone where the habitat is not suitable for them. According to Paongananet al. (2001), if average diameter of T. niloticus is $40.2 \mathrm{~mm}$, it will be found in zone depth of $0.1-3 \mathrm{~m}, 61.3 \mathrm{~mm}$ in $>3-5 \mathrm{~m}$ deep, $100.4 \mathrm{~mm}$ in $>5-8 \mathrm{~m}$ deep, and $117.8 \mathrm{~mm}$ in $>8-11 \mathrm{~m}$ deep.

Average size of basal diameter in four of these Trochus sp. types from high to low zone are different, the deeper of the waters, the bigger of average size. The same notion is also proposed by Poutiers (1998) that the deeper zone, the smaller number of population with the bigger size of eggshell. Differences on eggshell size in each zone is caused by adaptation to habitat, food and physiology of the biota. Besides, adaptation also relates to shelter searchings from predators such as fish, octopus and starfish.

\subsection{Density}

Analysis result on density value of Trochus sp. in intertidal zone can be seen in table 2 .

Table 2. Density of Trochussp in Intertidal Zone

\begin{tabular}{|c|c|c|c|c|c|}
\hline \multirow{3}{*}{ Intertidal Zone } & Area & \multirow{3}{*}{ Species } & Number & Density & Percentage \\
\hline & \multirow{2}{*}{ Observed $\left(\mathrm{m}^{2}\right)$} & & NuIner & Density & rercentage \\
\hline & & & (ind) & $\left(\right.$ ind $\mathrm{m}^{-2}$ ) & $(\%)$ \\
\hline \multirow{5}{*}{ High } & \multirow{5}{*}{8125} & T. niloticus & 42 & 0.00517 & 28.00 \\
\hline & & T. pyramis & 68 & 0.00837 & 45.33 \\
\hline & & T. maculatus & 21 & 0.00258 & 14.00 \\
\hline & & T.radiatus & 19 & 0.00234 & 12.67 \\
\hline & & \multicolumn{2}{|l|}{ Average } & 0.00462 & 100.00 \\
\hline \multirow{5}{*}{ Middle } & \multirow{5}{*}{8875} & T. niloticus & 29 & 0.00357 & 31.87 \\
\hline & & T. pyramis & 42 & 0.00517 & 46.15 \\
\hline & & T. maculatus & 10 & 0.00123 & 10.99 \\
\hline & & T.radiatus & 10 & 0.00123 & 10.99 \\
\hline & & average & & 0.00280 & 100.00 \\
\hline \multirow{5}{*}{ Low } & \multirow{5}{*}{3875} & T. niloticus & 10 & 0.00258 & 52.63 \\
\hline & & T. pyramis & 9 & 0.00232 & 47.37 \\
\hline & & T. maculatus & - & & \\
\hline & & T. radiatus & - & & \\
\hline & & average & & 0.00245 & 100.00 \\
\hline
\end{tabular}




\section{Macrothink}

Environmental Management and Sustainable Development

ISSN 2164-7682 2014, Vol. 3, No. 1

Table 2 shows that Trochus sp. is distributed in intertidal zone based on changes of waters depth where the deeper of depth the bigger of its size; on the contrary, the density decreases. This change is caused by changes of physiology, morphology and behavior. It is found that during juvenile phase, a sample of species T.niloticus lives in high intertidal zone and attaches to seaweed, lives in coral reef flatness during its adolescence phase and migrates to the deeper waters in its maturity phase. Kubo (1991) also found that in intertidal zone, Trochus sp. also depends on its life cycle. During its juvenile and adolescence phase, it populates coral reef flatness area and migrates to the deeper waters for the upcoming phase.

\subsection{Potency of Trochus sp.}

Potential degree is important for the continuity of waters resource management. Knowledge and technology are needed to manage this natural resource and they will only effectively play its role if there is data basis to calculate its potency and opportunity to be developed (Erwin and Laimena, 2002).

Analysis result on the potential degree of Trochus $s p$. in intertidal zone can be seen in Table 3 . It shows that Trochus $s p$. found in high zone has potency of 46 ind $^{-1} \mathrm{ha}^{-1}, 28$ ind ha ${ }^{-1}$ in the mid zone and 24 ind ha $^{-1}$ in the low zone.

Table 3. Potency of Trochus sp. in Intertidal Zone

\begin{tabular}{|c|c|c|c|c|c|}
\hline \multirow{3}{*}{$\begin{array}{l}\text { Intertidal } \\
\text { Zone } \\
\text { /Depth } \\
\text { (m) }\end{array}$} & Research & \multirow{3}{*}{ Trochussp } & Density & \multirow{2}{*}{\multicolumn{2}{|c|}{ Potency }} \\
\hline & Area & & & & \\
\hline & $\left(\mathrm{M}^{\wedge} 2\right)$ & & $\left(\right.$ types $\left.\mathrm{m}^{-2}\right)$ & (Ind) & (Ind/ha) \\
\hline \multirow{4}{*}{ High/0.1-2 m } & \multirow{4}{*}{41000} & T. niloticus & 0.00517 & 212 & 52 \\
\hline & & T. pyramis & 0.00837 & 343 & 84 \\
\hline & & T. maculatus & 0.00258 & 106 & 26 \\
\hline & & T. radiatus & 0.00234 & 96 & 23 \\
\hline \multirow{5}{*}{ Middle/2.0-3 m } & \multirow{5}{*}{48000} & \multicolumn{2}{|l|}{ Total } & 757 & \\
\hline & & T. niloticus & 0.00357 & 171 & 36 \\
\hline & & T. pyramis & 0.00517 & 248 & 52 \\
\hline & & T. maculatus & 0.00123 & 59 & 12 \\
\hline & & T. radiatus & 0.00123 & 59 & 12 \\
\hline \multirow{5}{*}{ Low/ 3.0-4 } & \multirow{5}{*}{22000} & \multicolumn{2}{|l|}{ Total } & 538 & \\
\hline & & T. niloticus & 0.00258 & 57 & 26 \\
\hline & & T. pyramis & 0.00232 & 51 & 23 \\
\hline & & T. maculatus & & 0 & 0 \\
\hline & & T. radiatus & & 0 & 0 \\
\hline
\end{tabular}

Potency of Trochus sp. decreases because habitat condition in high and mid zone is alleviating as the impact of people's activities in utilizing fishery potency, such as ornamental fish extraction, mollusks hunt at the ebb current and people's waste disposal. Indeed, it needs special handling method to protect the existing fishery resource sustainability in intertidal 


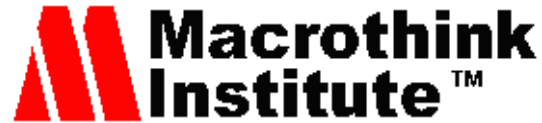

Environmental Management and Sustainable Development

ISSN 2164-7682

2014, Vol. 3, No. 1

zone that will deliver sustainable utilization. Ecosystem has an important role for juvenile growth, food and spawning (Indrawanet al . 2007).

\subsection{Diversity and Homogeneity of Trochus sp.}

Diversity and homogeneity value of Trochus sp.in intertidal zone can be seen in Table 4. Analysis result on diversity $\left(\mathrm{H}^{\prime}\right)$ of Trochus $s p$. shows that biota community in high and mid zone is steady moderate and unstable in the low zone. According Stirn (1981), if $\mathrm{H}^{\prime}<1$, biotic community is unstable, if $\mathrm{H}^{\prime}$ ranges from $1-3$, it is moderate and if $\mathrm{H}^{\prime}>3$, it means biotic community is sturdy (stable). The higher of $\mathrm{H}^{\prime}$ value, the more diverse of the organisms in the waters. It means that this is a better habitat.

Odum (1971) states that a community has a high diversity rate if its Shannon's diversity index is 4.0. High diversity of species in a community indicates that the community is complex. High diversity occurs when environmental condition in the deep sea is stable for a long time, so it allows the species to live through during that time up to specialization phase in order to inhabit macrohabitat or utilize certain feed (Shanders, 1968 in Nyabaken, 1980).

Table 4. Diversity and Homogeneity Value of Trochus sp. in Intertidal Zone

\begin{tabular}{|c|c|c|c|c|c|c|}
\hline Intertidal & \multirow{2}{*}{ SPECIES } & \multirow{2}{*}{ ni } & \multirow{2}{*}{$\mathrm{Pi}$} & \multirow{2}{*}{$\ln \mathrm{Pi}$} & \multirow{2}{*}{ PiLnPi } & \multirow{2}{*}{$\mathrm{E}$} \\
\hline Zone & & & & & & \\
\hline \multirow{6}{*}{ High } & T. niloticus & 42 & 0.28 & -1.27 & -0.3564 & \multirow{6}{*}{0.90} \\
\hline & T. pyramis & 68 & 0.45 & -0.79 & -0.3586 & \\
\hline & T. maculatus & 21 & 0.14 & -1.97 & -0.2753 & \\
\hline & T. radiates & 19 & 0.13 & -2.07 & -0.2617 & \\
\hline & Number of individual $(N)$ & 150 & \multirow{2}{*}{\multicolumn{2}{|c|}{$\begin{array}{r}\mathrm{H}^{\prime} \\
\mathrm{H}^{\prime} \max \end{array}$}} & 1.25205 & \\
\hline & Number of species $(S)$ & 4 & & & 1.38629 & \\
\hline \multirow{6}{*}{ Middle } & T. niloticus & 29 & 0.32 & -1.14 & -0.3644 & \multirow{6}{*}{0.87} \\
\hline & T. pyramis & 42 & 0.46 & -0.77 & -0.3569 & \\
\hline & T. maculatus & 10 & 0.11 & -2.21 & -0.2427 & \\
\hline & T. radiates & 10 & 0.11 & -2.21 & -0.2427 & \\
\hline & Number of individual $(N)$ & 91 & & $\mathrm{H}^{\prime}$ & 1.20662 & \\
\hline & Number of species $(S)$ & 4 & & H'max & 1.38629 & \\
\hline \multirow{6}{*}{ Low } & T. niloticus & 22 & 0.59 & -0.52 & -0.3091 & \multirow{6}{*}{0.97} \\
\hline & T. $\quad$ pyramis & 15 & 0.41 & -0.90 & $-0,366$ & \\
\hline & T. maculatus & 0 & & & & \\
\hline & T. radiates & 0 & & & & \\
\hline & Number of individual $(N)$ & 37 & & $\mathrm{H}^{\prime}$ & 0.67514 & \\
\hline & Number of species $(S)$ & 2 & & $H^{\prime} \max$ & 0.69315 & \\
\hline
\end{tabular}

Homogeneity value of Trochus sp. in PulauRhun waters in the three intertidal zones is high (e > 0.75), where the existence of biota is distributed, so there is no dominant species. If homogeneity value is close to zero, it means that homogeneity of inter-species in the community is low. On the contrary, if the homogeneity value is close to one, it can be said that homogeneity of inter-species is even or equal (Pirzanet al. 2005). Specifically for Trochus sp. in this ecosystem, there is no tendency of certain species domination which is 
caused by the existence of environmental factors instability. According to Brower and Zar (1977), diversity will moderate and homogeneity will high if species abundance is equal or nearly equal, and if only some species is plenteous, species diversity will be low.

\subsection{Dominance Index}

Analysis result on dominance index of Trochus sp. in intertidal zone can be seen in the following Table 5:

Table 5. Domination Index Value of Trochus sp.in Intertidal Zone

\begin{tabular}{|c|c|c|c|c|c|c|c|}
\hline \multirow{2}{*}{$\begin{array}{c}\text { Intertidal } \\
\text { Zone }\end{array}$} & \multirow{2}{*}{$\begin{array}{l}\text { Species } \\
\text { Trochussp }\end{array}$} & \multicolumn{6}{|c|}{ Dominance Index } \\
\hline & & $\mathrm{S}$ & $\mathrm{N}$ & ni & $\sum \mathrm{Di}$ & $\mathrm{D}$ & Note \\
\hline \multirow{4}{*}{ High } & T. niloticus & 150 & 42 & 66 & 0.00058 & \multirow{4}{*}{0.0061} & \multirow{4}{*}{ less dominant } \\
\hline & T. pyramis & 150 & 68 & 122 & 0.00022 & & \\
\hline & T. maculatus & 150 & 21 & 27 & 0.00238 & & \\
\hline & T. radiatus & 150 & 19 & 29 & 0.00292 & & \\
\hline \multirow{4}{*}{ Middle } & T. niloticus & 91 & 29 & 65 & 0.00123 & \multirow{4}{*}{0.0240} & \multirow{4}{*}{ less dominant } \\
\hline & T. pyramis & 91 & 42 & 88 & 0.00058 & & \\
\hline & T. maculatus & 91 & 10 & 26 & 0.01111 & & \\
\hline & T. radiatus & 91 & 10 & 16 & 0.01111 & & \\
\hline \multirow{2}{*}{ Low } & T. niloticus & 37 & 22 & 51 & 0.00216 & \multirow[t]{2}{*}{0.0069} & \multirow[t]{2}{*}{ less dominant } \\
\hline & T. pyramis & 37 & 15 & 31 & 0.00476 & & \\
\hline
\end{tabular}

Analysis result on dominance index value (D) of Trochus sp.shows low value meaning that there is no specific species domination in the waters. If dominance index value is close to 1 , it refers to a condition where one species dominates the others in the community. On the contrary, if its value is close to zero, it means there is no extreme domination of one species toward the others in the community. In order to avoid certain species domination in Rhun Island waters, coral reef and seaweed bed preservation as well as exploitation prohibition to certain areas (nurture place) are need to be done.

\subsection{Distribution Pattern}

Analysis result on distribution pattern value of Trochus sp. in intertidal zone can be seen in the following table 6.

Table 6. Distribution Pattern of Trochus sp. in Intertidal Zone

\begin{tabular}{|c|c|c|c|c|c|c|}
\hline \multirow{2}{*}{$\begin{array}{l}\text { INTERTIDAL } \\
\text { ZONE }\end{array}$} & \multirow{2}{*}{$\begin{array}{l}\text { SPECIES } \\
\text { Trochussp }\end{array}$} & \multicolumn{5}{|c|}{ Distribution Pattern } \\
\hline & & $n$ & $\sum \mathrm{x}$ & $\sum \mathrm{x}^{2}$ & $\mathrm{Id}$ & Note \\
\hline \multirow{4}{*}{ High } & T. niloticus & 150 & 42 & 66 & 2.09 & Clumped \\
\hline & T. pyramis & 150 & 68 & 122 & 1.78 & Clumped \\
\hline & T. maculatus & 150 & 21 & 27 & 2.14 & Clumped \\
\hline & T. radiatus & 150 & 19 & 29 & 4.39 & Clumped \\
\hline \multirow{4}{*}{ Middle } & T. niloticus & 91 & 29 & 65 & 4.03 & Clumped \\
\hline & T. pyramis & 91 & 42 & 88 & 2.43 & Clumped \\
\hline & T. maculatus & 91 & 10 & 26 & 16.18 & Clumped \\
\hline & T. radiatus & 91 & 10 & 16 & 6.07 & Clumped \\
\hline \multirow{2}{*}{ Low } & T. niloticus & 37 & 22 & 51 & 2.32 & Clumped \\
\hline & T. pyramis & 37 & 15 & 31 & 2.82 & Clumped \\
\hline
\end{tabular}




\section{Macrothink}

Analysis result on distribution pattern (Id) of Trochus sp.show a clumped pattern. Odum (1971) states that clumped pattern is the most common pattern, while the random one is rarely found in nature because it exists in a very homogeneous nature. Distribution pattern of Trochussp found in intertidal zone of Rhun Island waters is clumped. It relates to habitat structure especially for the distribution pattern of coral blocks as the settlement and shelter from predators as well as microalgae and macroalgae distribution. Nurdin et al (2009) states that substrate type and environment effects such as salinity and temperature affects gastropods distribution. The same finding stated by Tarumingkeng (1994) proposes that organism tends to form a clumped pattern as an effort to forage, breed and defend from the predators attack.

\section{Conclusion and Suggestion}

\subsection{Conclusion}

Based on the findings and discussion, it can be concluded as follows:

1. There are four types of Trochus sp. found in research site. The dominant species in high and mid zone is T. Pyramis, while the dominant species found in low zone is T.niloticus.

2. Average size of basal diameter from the four species Trochus sp. increases along with the increasing of waters depth, it occurs conversely to the density.

3. Potency of Trochus sp.in high zone is 46 ind ha ${ }^{-1}, 28$ ind ha ${ }^{-1}$ in mid zone and 25 ind ha ${ }^{-1}$ in the low zone.

4. Diversity index value of Trochus sp.in high and mid zone is moderate (medium) and unstable (low) in low zone.

5. Diversity index of Trochus sp.in the three intertidal zones of Rhun Island waters is high.

6. Dominance index of Trochus sp.in the three zones is low.

7. Distribution pattern of Trochus sp. found in intertidal zone is clumped based on habitat structure and food.

\subsection{Suggestion}

It is suggested that there is the needs to do habitat improvement in intertidal zone in order to improve population diversity by performing rehabilitation on coral condition and alleviating people's activities in intertidal zone.

\section{References}

Anonim. (2001). Kecamatan Banda Dalam Angka. Biro Pusat Statistik. Jakarta.

Arifin Z. ,dan Pradina. (1993). Struktur Jaringan Beberapa Organ Dalam T. niloticusL. Perairan Maluku Dan Sekitarnya.

Brower, J.E, \& Zar J.H. (1977). Field and Laboratory Methods for General Ecology. Iowa: WM. J Brown Company Publ. Dubuque. 94 p. 


\section{Ml Macrothink}

Environmental Management and Sustainable Development

ISSN 2164-7682 2014, Vol. 3, No. 1

Dahuri R, PuteraLNS, Zairon, \& Sulistino. (1993). Metode dan Teknis Analisis Biota Pertanian. Pusat Penelitian Lingkungan Hidup Lembaga Penelitian Institut Pertanian Bogor. Bogor.

Dolorosa, R. G., Songco A. M., Calderon V., Magbanua R. \& Marillano J. A. (2010). Population structure and abundance of Trochus niloticusin Tubbataha Reefs Natural Park, Palawan, Philippines with notes on poaching effects. SPC Trochus Information Bulletin.

Erwin, H dan Laimena P. (2002). Potensi Pemanfaatan Beberapa Jenis Keong Laut (Moluska: Gastropoda) The Used of Sea Snails (Mollusc: Gastropod) JurusanBiologi, FMIPA, Universitas Pattimura, Jurnal Hayati, September 2002, hlm. 97-99 Vol. 9, No. 3 ISSN 0854-8587.

Hartati S T. \& Awaluddin. (2007). Struktur komunitas makro zoobentos di perairanTeluk Jakarta. Perikanan Indonesia, 13(2), 105-124.

Indrawan, M., Primack R. B., \& Supriatna, J. (2007). BiologiKonservasi, EdisiRevisi: YayasanObor Indonesia. Jakarta. pp. 625.

Nurdin, J, Suprijatna J, Budiman \& Patria M.P. (2009). The Potential Edible Bivalve and its diversity in costal water of South Kabung bay, Wets Sumatra: With spacial case of gafrariumtumidum (Roding 1798). The Poster at the International Seminar $2^{\text {nd }}$ Joind Seminar UI-FST UKM at Bagin Campus, Malasysia”, 22-23 Juni 2009.

Nurdin, J., Suprijatna J., Budiman A dan Patria M.P. (2010). Keanekaragaman Gastropoda dan Bivalvia diperairan pantai teluk Panasahan Painan Sumatera Barat. Jurnal Biologi Universitas Andalas, Padang. Depertemen Biologi Universitas Indonesia, Depok. Zoologi. Lembaga Ilmu Pengetahuan Indonesia. Cibinong.

Khouw AS. (2009). Metode Analisa Kuantitatif dalam Bioekologi Laut. Penerbit Pusat Pembelajaran dan Pengembangan Pesisir dan Laut (P4L).

Krebs, C.J. (1989). Ecological methodology. New York: Harper Collins Publishers, Inc.

Kubo, H. (1991). Study on seed releasing of trochus Okinawa. Perfectural Fisheries experimental station report. In Japanese. English translation by Jiroisa.FAO.SPADP. Suva, Fiji. 21pp.

Lalli CM. \& Parsons, T.R. (2001). Biological oceanography, an introduction. Second edition.Pergamon Press. Oxford. 357p

Nybakken, J. W. (1998). Biologi Laut, Suatu Pengantar Ekologi, PT. Gramedia Pustaka Utama Jakarta.

Odum, E. P. (1971). Fundamental Of Ecologi $3^{\text {rd }}$ Eds. W. B. Sounders Company Phicadelphia. $574 \mathrm{pp}$.

Paonganan, Y, Winanto T \& E.Soekendarsi. (2001). Size distribution of male andfemale top shell Trochus niloticus Linne in relation to the depth and substrate. Phuket marine biological center special publication, 25 (1), $89-90$. 


\section{Macrothink}

Environmental Management and Sustainable Development

ISSN 2164-7682 2014, Vol. 3, No. 1

Pirzan A M, Utojo, Atmomarso M, Tjaronge M, Tangko A M danHasnawi. (2005). Potensi lahan budidaya tambak dan laut di Kabupaten Minahasa, Sulawesi Utara. Jurnal Penelitian Perikanan Indonesia, 11 (5), 43-5 .

Purnomowati, R. (2001). Kajian Pengelolaan Sumberdaya Pesisir Berbasis Masyarakat (Kasus Desa Pemongkong, Kecamatan Keruak, Kabupaten Lombok Timur, NTB). Program Pascasarjana Instutut Pertanian Bogor. 124 hal

Poutiers, J. M. (1998). Gastropoda in the Living Marine Resaurces of the Western Central Pacific. Vo.1.Eds. K E. Carpenter and N. H. Niem.Food and Agriculture Organization of the United Nations, Rome 689p.

Stirn, J. (1981). Manual Methods in Aquatic Environment Research. Part 8 Rome: Ecological Assesment of Pollution Effect, FAO.

Tarumingkeng, R. C. (1994). Dinamika Populasi Kajian Ekologi Kuantitatif. Pustaka Sinar Harapan Dan Universitas Kristen. Krida. Wacana Jakarta.

Woodhams J., \& Rodger M. (2009). 18 Torres Strait Sea Cucumber and Trochus Fisheries. Fishery status reports 2009.

\section{Copyright Disclaimer}

Copyright reserved by the author(s).

This article is an open-access article distributed under the terms and conditions of the Creative Commons Attribution license (http://creativecommons.org/licenses/by/3.0/). 